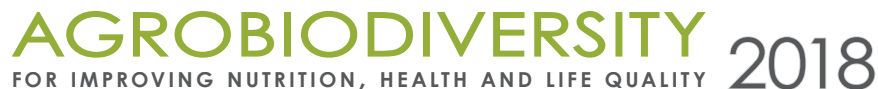

$\odot$

\section{MICROBIOLOGIC, AGROCHEMICAL AND AIIELOPATHIC SOIL STATUS UNDER LAVANDULA L. PLANTS SPECIES IN FOREST-STEPPE ZONE}

\section{Yunosheva Olena*, Ellanska Natalia}

M. M. Gryshko National Botanical Garden, National Academy of Sciences of Ukraine, Kyiv, Ukraine

\author{
Received: 15. 11.2018 Revised: 28. 11.2018 Published: 10. 12. 2018
}

\begin{abstract}
The article reports the results of microbiological, agrochemical and allelopathic studies of the influence of Lavandula angustifolia Mill. and Lavandula hybrida Rev. introductive plants on the soil status. The aim of this study was to analyze the effect of hydrothermal and soil conditions of Forest-Steppe zone on the microbial cenosis formation and dynamics of taxonomic and ecology-trophic groups of microorganisms, the soil allelopathic activity and the ratio of biogenic elements. The analysis of the functional structure of microbial cenosis in the rhizosphere of lavender and lavandin shows a decreased quantity of micromicetes and an increase in the amount of spore-forming bacteria. The allelopathic activity of soil under lavender is characterized by a low level of toxicity. The processes of mineralization of organic matter in the soil were quite balanced. The influence of allelochemicals on the distribution of macro and microelements in the soil during lavender cultivation has been studied. The obtained results prove the positive effect of the studied plants on the microbiocenose and physical-chemical soil state that should be taken into account for their gardening.
\end{abstract}

Keywords: Lavandula, microbiocenosis, micromycetes, bacteria, soil allelopathic activity.

\section{Introduction}

Nowadays the disturbingly increasing anthropogenic effect on natural ecosystems leads to the reduction of the biological diversity of plant, animal and microbial world. The problem of preservation of phytobiodiversity can be solved out by means of sinecologic methods of plant introduction into the artificial phytocoenosis.

Aromatic plant species are characterized by polyfunctional properties as they are resistant to various anthropogenic pollutants and phytopathogenic microorganisms and do not accumulate phytotoxic substances in their environment, causing the phytosanitary effect on the ecosystem (Yurchak, 2005; Kovtun-Vodyanytska, 2017).

The species of Lavandula L. genus are known for their ability to influence the environment because of their high allelopathic activity. Moreover, the plants of Lavandula genus are popular

Corresponding author: Yunosheva Olena, Gryshko National Botanical Garden, National Academy of Sciences of Ukraine, 1, Timiriazevska str., Kyiv 01014, Ukraine vandae@ukr.net 
horticultural species as they are characterized by long flowering period, high ionizing sanitary effect and do not require special growing conditions.

The role of biologically active substances and the associated microbiota of culturphytocoenosis of Salvia sclarea L., Lavandula angustifolia and Mentha piperita L. aromatic plants were studied by Yurchak $(1999,2005)$. We had earlier characterized the formation of the microbiocenosis in the soil samples under Monarda didima L., Hyssopus officinalis L. Dracocephalum moldavicum L., Vitex agnus-castus L. plant species of Lamiaceae family (Ellanska, 2010, 2013)

This way, the aim of this study was to characterize the main taxonomic and ecotrophic groups of microorganisms and to estimate the allelopathic activity of soil under the plants of Lavandula genus under the conditions of Forest-Steppe zone.

\section{Materiall and methodology}

\section{Locating plants and data collection}

This experimental study was carried out in the Department of Allelopathy of M.M. Gryshko National Botanical Garden of the National Academy of Sciences of Ukraine (Kyiv). Lavandula angustifolia Mill. and Lavandula hybrida Rev. plants were donated by the Botanical garden collection fund.

\section{Microbiological researches}

The bacterial abundance was quantified on meat-peptone agar (for ammonifiers), on ammonium starch agar (for inorganic nitrogen-immobilizers and actinomycetes), on Mishustin medium (spore-forming bacteria), on Hetchenson medium (cellulose decomposing bacteria), on Eshbi medium (for nitrogen-fixing bacteria by the application method), while the microscopic fungi were incubated on Capek medium. The ratio of certain ecological-trophic groups of microorganisms (mineralization-immobilization index) was calculated according to Andreyuk (2001), the index of organic matter transformation was analyzed by the method of Mucha (1980). We calculated the number of colony-forming units (GFU/g) of soil bacteria, taking into account the dilution of soil samples according to standard- accepted methods (Tepper, 2004).

\section{Analysis of soil allelopathic activity}

The estimation of soil allelopathic activity was carried out by direct bioassay method (Grodzinskij, 1990). Garden cress (Lepidium sativum L.) and winter wheat (Triticum aestivum L.) plants were used as test cultures. The soil samples with no influence of exometabolites of the studied plants were considered control ones.

\section{Agrochemicals analysis}

The content of macro- and trace elements in the root-soil soil was determined by the method of Rink's (1982) spectrometer with inductively coupled plasma ICAR 6300 DUO (USA). The obtained results were statistically processed using Microsoft Office 2007 software suite. 
When presenting the results we have also taken into account the number of precipitations throughout the plant vegetation period (I group - the years characterized by the lower level of precipitations, II group - the years characterized by the higher level of precipitations).

\section{Results and discussion}

Microorganisms are considered an important consortium of agrophytocenoses and an indicator of fertility, biological activity and allelopathic state of soil (Yunosheva and Ellanskaya, 2015; Ellanskaya and Gorelov, 2017).

A distinctive feature of the aromatic plants is their production of essential oils. The lavender's soil microbiota forms under influence of its plant's excretions, in particular, essential oils, that have a specific effect on the functional structure of the microbiocenosis and organic matter decomposition (Vokou, 2002; Hassiotis, 2010).

Here we firstly analyzed the abundance and the ratio of basic taxonomic and eco-trophic microorganism groups of lavender rhizosphere microbial cenosis and inter-row soil under soil conditions of Forest- Step zone. The number of micromycetes was shown to decrease during the flowering period especially for the years characterized by the lower level of precipitations when comparing to the control samples (Figure 1).

At the same time, the abundance of these microorganisms was 1.5-2.0 time-lower in case of the rhizosphere samples of the studied plants than for the ones of the inter-row soil.

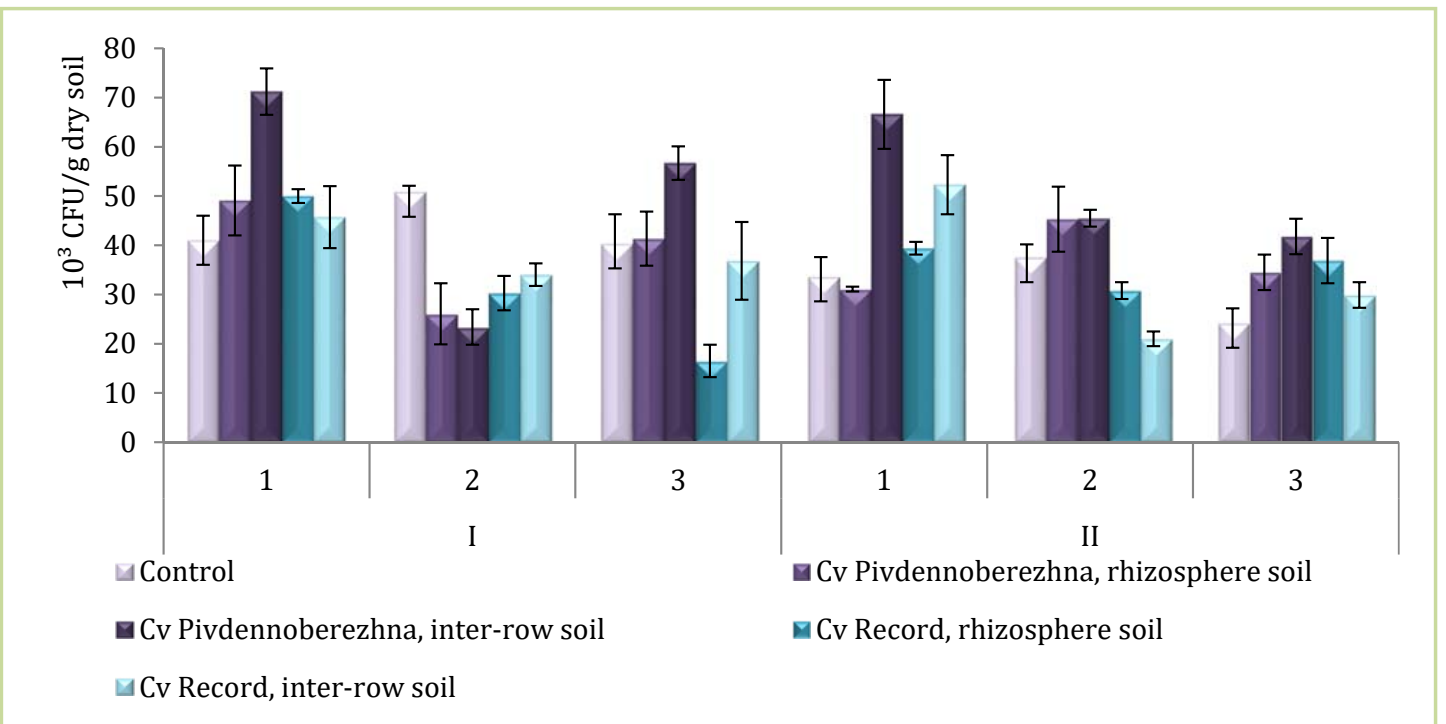

Figure 1 Micromycetes abundance in the soil samples under Lavandula angustifolia plants: 1 - growing stage; 2 - flowering stage; 3 - seed formation stage; I group - the years characterized by a lower level of precipitations; II group - the years characterized by higher level of precipitations

Lavender rhizosphere was characterized by a wider spectrum of micromycete species of Penicillium and Trichoderma genera comparing to the control ones (mostly the mucoral 
forms). The noteworthy fact is that Aspergillus species were found in the studied soil samples probably due to the species-specific secretions of lavender plants. The quantitative parameters of spore bacteria growth were 1.4-2.4 times higher compared to control ones throughout all the phases of plant development. The abundance of ammonifiers, cellulosedestroying microorganisms and actinomycetes appeared to be increased in the studied soil samples. The development of nitrogen-fixing microorganisms was inhibited by up to $80 \%$ throughout the entire period of lavender plant vegetation during the years characterized by lower water availability, whereas such an inhibition did not exceed $16-19 \%$ for the years characterized by more precipitations.

Ammonifiers were shown to develop more intensively during the lavender emergence and flowering periods, their abundance declining by the end of vegetation period (Table 1).

The general abundance of nitrogen-fixing bacteria was descending throughout the vegetation period mostly in rhizosphere zone. During the years characterized with the higher water availability the abundance of microorganisms can be stated as relatively high, this parameter decreasing being observed only during the plant flowering period.

Basing the obtained results the processes of mineralization of organic matter in the soil appeared quite balanced. The mineralization-immobilization ratio during active plant vegetation period proved the accumulation of organic compounds, whereas the mineralization processes became more active at the end of the growing season.

The development of microorganisms in the soil samples under lavandin plants was characterized by analogical peculiarities to that of lavender ones (Figure 2). The representatives of Penicillium, Trichoderma, Fusarium, Gliocladium genera dominated. Spore-forming bacteria were developing much active during the flowering and seed formation periods. The actinomycete abundance prevailed in lavandin rhizosphere throughout all its vegetation periods. The positive development of nitrogen-fixing microorganisms was observed with only its slight inhibition during the flowering period for the years characterized by low precipitation level.

The results of our study correspond the developmental characteristics of the microbiocenosis of the other representatives of aromatic plant species of Lamiaceae family. The similar trends of the micromycete ratio was reported for the soil samples of Monarda didima та Dracocephalum moldavicum, their abundance declining in 2-5 times during germination and flowering periods comparing to the control ones. The decreasing of micromycete abundance in the rhizoshpere samples was also observed for the flowering period of Salvia sclarea L. and representatives of Vitex genera (Yurchak, 1997; Ellanska, 2013). The root and volatile exometabolites of lavender may inhibit this group of microorganisms. The increasing abundance of spore-forming bacteria, actinomycete, ammonifires was reported for microbcenosis of the soil under the Salvia sclarea, Monarda didima and Mentha piperita plants (Yurchak, 2005; Ellanska, 2010).

Consequently, the formation of microbiocenosis depends on several factors of climatic and soil conditions and plant species. The allelopathically active plant substances (essential oils, phenolcarboxylic acids) may become one of the microbe biomass regulators. 


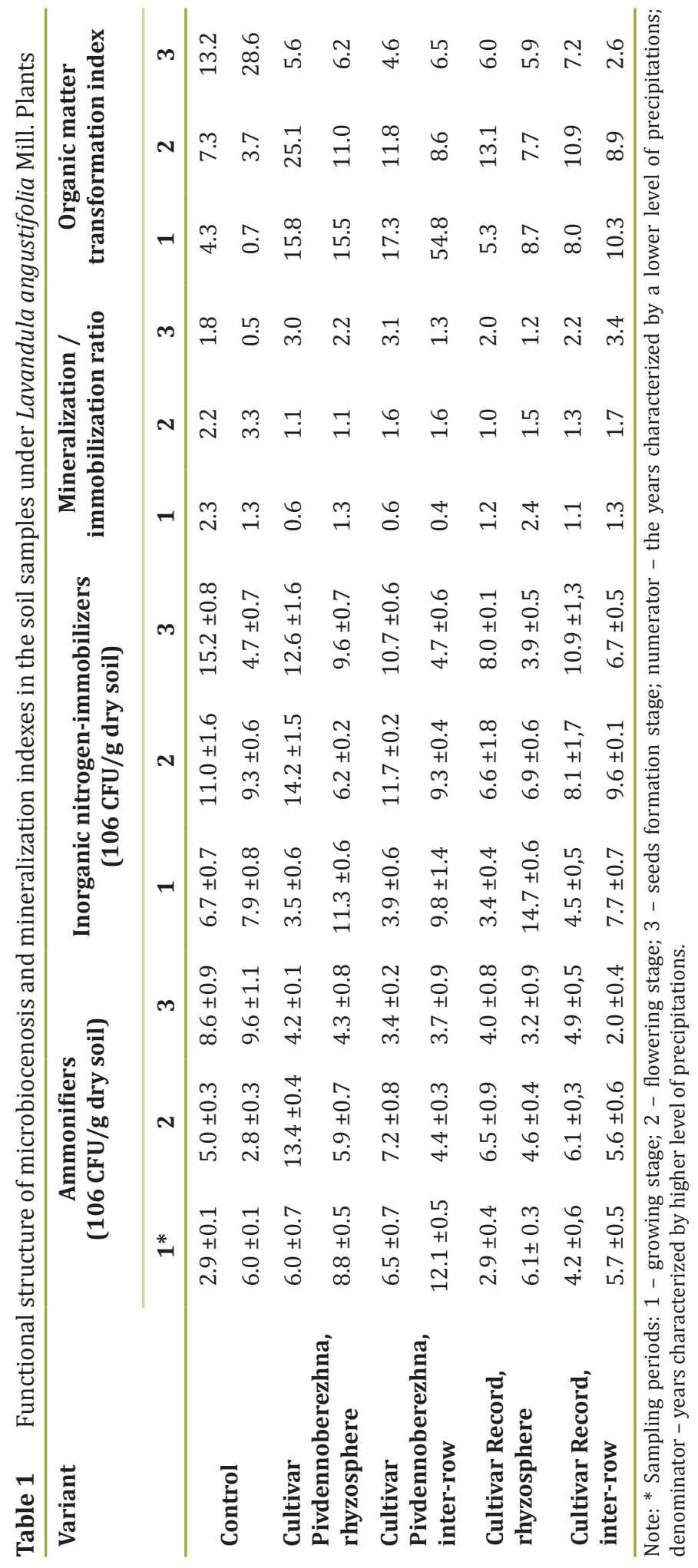


The mineral substances are known for their key role in plant functioning and development as well as in the increasing of their resistance to abiotic and biotic environmental factors. The analysis of the content of biogenic elements in the soil samples under lavender and lavandin plants proved the tendency of decreasing of ammoniac nitrogen content starting from the blossoming period and increasing of nitrate-nitrogen concentration at the end of vegetation period. The phosphorus concentrations didn't significantly differ for the studied samples. The beginning and the end of the vegetation periods were characterized by rising of potassium amounts. The maximum magnesium concentration was detected for lavender rhizosphere during the seed formation period. The end of vegetation period was characterized by the $40 \%$ increase of magnesium concentration in the studied soil samples while its twice decreasing was shown for the control ones. The declining of iron content (up to 33\%) was observed for all the rhizosphere soil samples of the studied plants during the growing season. The obtained results prove the positive effect of the studied plants on the physical-chemical soil state that should be taken into account for their gardening.

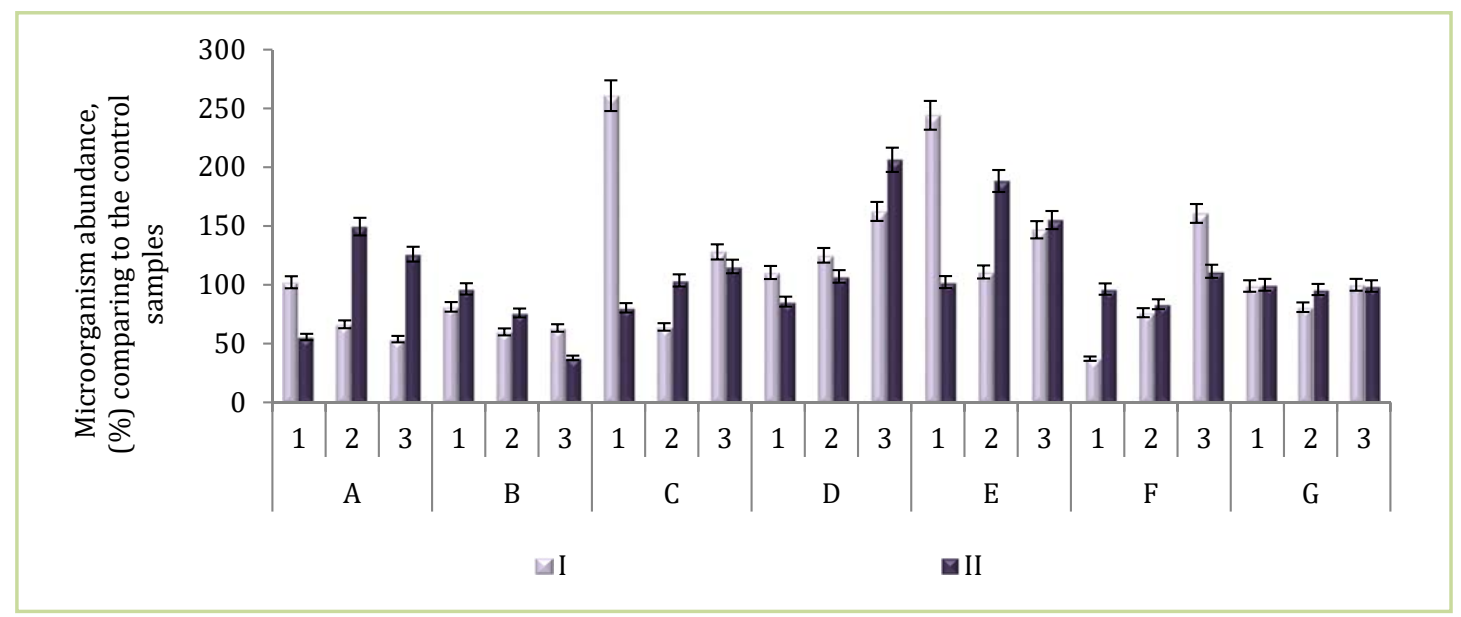

Figure 2 Microbial abundance in the soil samples under Lavandula hybrida Rev. plants: 1 - growing stage; 2 - flowering stage; 3 - seed formation stage; A - ammonifiers; B - inorganic nitrogenimmobilizers; $\mathrm{C}$ - micromycetes; D - spore-forming bacteria; E - actinomycetes; F-cellulosolytic; G - nitrogen-fixing; I group - the years characterized by the lower level of precipitations; II group - the years characterized by the higher level of precipitations

The toxicity of the lavender rhizosphere was considerably lower under the Forest-Steppe conditions compared to the conditions in the southern regions of Ukraine (Yurchak, 2005). The soil allelopathic activity depended on the water balance, as its effect appeared (basing the analyzed parameters) lower for the years characterized by high precipitation level and higher one for the arid years. The obtained data corresponding to the hypothesis that the level of soil toxicity depends on the intensity of essential oil adsorption, which is influenced by the precipitation level. 


\section{Conclusions}

Therefore, the exometabolites of lavender and lavandin plants caused the 1.7-1.9 time decreasing of micromycete abundance in the rhizosphere. We also report the significant (in 1.4-2.4 times) increasing of spore-forming bacterium abundance and the improved development of actinomycetes, ammonifiers, cellulosolytic microorganisms. Basing the obtained results the processes of mineralization of organic matter in the soil appeared quite balanced. The allelopathic activity of the soil samples under lavender and lavandin plants was characterized by low toxicity level for the biotests. The soil allelopathic activity was proved to depend on the water availability: its characteristics were lower for the years of higher precipitation level and higher ones for the arid years. The microbiological analysis of the soil samples under the studied plants proved the variable microorganism biodynamics in the rhizosphere and inter-row samples of the aromatic plants as the periods of increasing or decreasing of microbiota abundance can be logically explained by the plant taxonomy, the geographical and climate conditions, the phases of plant development, the intensity of their physiological processes. Microbiologic, agrochemical and allelopathic soil status under Lavandula angustifolia Mill. and Lavandula hybrida Rev. plant species under the Forest-Steppe zone conditions was found out favourable for the successful introduction of these plants.

\section{Acknowledgements}

We are grateful to Luchakivska Yuliya for her help in this article translation.

\section{References}

ANDREJUK, K.I., IUTYNSKA, G.O., ANTYPCHUK, A.F., VALAGUROVA, O.V., KOZYRYTSKA, V.Y, PONOMARENKO, S.P. 2001. Funkcionuvannya mikrobny'x cenoziv g'runtu $v$ umovax antropogennogo navantazhennya [Soil microbial cenosis functioning under conditions of anthropogenic load]. Kyiv: Naukova dumka. 240 p. [In Ukrainian].

ELLANSKAJA, N.E., GNATIUK, N.O., YUNOSHEVA, O.P., CHOCHLOVA, I.G. 2010. Osoblivosti formuvannya mikrobiotsenoziv u gruntah pid aromatichnimi roslinami [The features of microbocenoses formating under aromatic plants in some soils]. In Sci. Bull. Uzhgorod Univ. (Ser. Biol.), vol. 27, p. 29-33 [In Ukrainian].

ELLANSKAJA, N. E., LEVCHYK, N.Y., YUNOSHEVA, O.P. 2013. Mikrobni ugrupovannya pry`korenevogo gruntu predstavnykiv rodu Vitex L. [Rhizospere microbial community of genus Vitex L. representatives]. In Gruntoznavstvo, 2013. vol. 14, no. (1-2), p. 61-69. [In Ukrainian].

ELLANSKAJA, N.E., GORELOV, A.A. 2017. Osobennosti formirovaniya mikrobnogo cenoza prikornevoj pochvy Alnus glutinosa (L.) GAERTN. [Features of microbial cenosis forming of Alnus glutinosa (L.) GAERTN. root soil]. In Agrobiodiversity for improving Nutrition, Health and Quality, vol. 1, p. 122-126. http://dx.doi.org/10.15414/agrobiodiversity.2017.2585-8246.122-127 [In Ukrainian].

GRODZINSKIJ, A.M. et al. 1990. Pryamye metody biotestirovaniya pochvy i metabolitov mikroorganizmov [Direct methods of biotesting of soil and metabolites of microorganisms]. In Allelopathy and plant productivity. Kyiv : Naukova dumka, p. 121-124. [In Russian].

HASSIOTIS, C. N., DINA, E. I. 2010. The Influence of Aromatic Plants on Microbial Biomass and Respiration in a Natural Ecosystem. In Israel Journal of Ecology \& Evolution, vol. 56, p. 181-196. https://doi. org/10.1560/IJEE.56.2.181 
KOVTUN-VODYANYTSKA, S. 2017. Predstavniki rodini Lamiaceae LINDL. v kolekciï netradicijnih efironosnih roslin Nacional'nogo botanichnogo sadu im. M. Grishka NAN Ukraïni [Representatives of Lamiaceae Lindl. Family in collection of non-traditional aromatic plants of M.M. Gryshco national botanical garden of NAS of Ukraine]. In Agrobiodiversity for improving Nutrition, Health and Quality, vol. 1, p. 249-252. http://dx.doi.org/10.15414/agrobiodiversity.2017.2585-8246.249-252 [In Ukrainian]

MUKHA, V.D., 1980. O pokazatelyah, otrazhayuschih intensivnost i napravlennost pochvennyih protsessov. [About characteristics, reflecting intensity and directivity of soil processes] Edited volume of Kharkov agriculture institute, Kharkov, vol. 273, pp. 13-16. [In Russian]

RINKIS, G.Y, NOLLENDORF, V.F. 1982. Sbalansirovannoe pitanie rastenij makro- i mikroehlementami [Balanced plants nutrition with macro and microelements]. Riga: Zinatne, 304 p. [In Russian].

TEPPER, E.Z. et al., 2004. Praktikum po mikrobiologii [Microbiology practicum]. Moscow : Drofa, 256 p. [In Russian].

VOKOU, D, CHALKOS, D., KARAMANLIDOU, G. et al. 2002. Activation of soil respiration and shift of the microbial population balance in soil as a response to Lavandula stoechas essential oil. In J Chemical Ecology, vol. 28(4), p. 755-768. https://doi.org/10.1023/A:1015236709767

YUNOSHEVA, O., ELLANSKA, N. 2015. Cpecyfika mikrobnyx ugrupovan gruntu introdukovanyx roslyn Lavandula angustifolia Mill. [Specific features of soil microbial communites under Lavandula angustifolia Mill. introducted plants]. Gruntoznavstvo, vol. 14(1-2), p. 61-69. [In Ukrainian].

YURCHAK, L.D., POBIRCHENKO, G.A. 1997. Kultura shalfeya muskatnogo v Lesostepi Ukrainyi [Sage Muscat Culture in the Forest-Steppe of Ukraine] Kyiv: Naukova dumka, 166 p. [In Ukrainian].

YURCHAK, L.D. 2005. Allelopatiya $v$ agrobiogeocenozax aromaty'chny'x rosly'n [Allelopathy in agrobiogeocenoses of aromatic plants]. Kyiv : Phitosociotcentr, 411 p. [In Ukrainian].

ZVYAGINCEV, D.G. et al. 1991. Metody pochvennoj mikrobiologii i biohimii [Methods of Soil Microbiology and Biochemistry]. Moskva : Izdatel'stvo MGU. 303 p. [In Russian]. 